\title{
Work Opportunities and Organizational Commitment in International Organizations
}

To cite this article:

Giauque, D., \& Varone, F. (2018). Work Opportunities and Organizational Commitment in International Organizations. Public Administration Review, O(0). doi:10.1111/puar.12951

Authors:

David Giauque

Associate professor

University of Lausanne

Institute of political, historical, and international studies (IEPHI)

Geopolis

1015 Lausanne

Switzerland

Email: David.Giauque@unil.ch

Frédéric Varone

Professor

University of Geneva

Political Science and International Relations Department

40 boulevard du Pont d'Arve

1211 Genève 4

Switzerland

Email: frederic.varone@unige.ch

Short biographies of the authors:

David Giauque is an associate professor of sociology of organizations and public administrations at the University of Lausanne. He is the author and coauthor of numerous books and scientific articles with respect to the following topics: public administration reforms; public management; human resource management in the public sector; sociology of public administrations.

Frédéric Varone is full professor of political science at the University of Geneva. His research interests include comparative policy analysis, public administration, program evaluation, interest groups and political elites. He is the coauthor of the Public Policy Process (Routledge, 2017). 


\begin{abstract}
This article applies social exchange theory to investigate the relationships between work opportunities and organizational commitment in four United Nations agencies. It demonstrates that international civil servants who are satisfied with altruistic, social, and extrinsic work opportunities are more likely to declare high levels of organizational commitment. Furthermore, the perceived organizational support mediates these relationships. The empirical findings highlight the importance of considering the specificity of organizational features in explaining international civil servants' attitudes and behaviors. Their preferences for altruistic, social, and extrinsic work opportunities are not similar to the motivational orientations and rewards valued by public- or privatesector employees, thus confirming the hybrid characteristics of international organizations. Drawing on these original results, this research also identifies some practical implications for human resources management in international organizations.
\end{abstract}

Evidence for Practice

- Organizational work opportunities may contribute to shape organizational commitment in international organizations.

- International organizations do possess some hybrid characteristics, which may impact on employees' organizational commitment.

- Altruistic, social, and extrinsic work opportunities are important antecedents of organizational commitment in international organizations.

- Perceived organizational support is of great importance as well. 
Keywords: international organizations, international civil service, organizational commitment, work opportunities, organizational support 


\section{Introduction}

Studies comparing organizational features in the public and private sectors have investigated preferences for work opportunities, values, or incentives (Rainey and Bozeman 2000; Rainey 1983). By contrast, administrative officials working at the international level are not usually included in comparative human resources (HR) management studies. This situation is quite surprising since international organizations (IOs) are key players that influence all societal fields and political levels (Devin and Smouts 2011). A better understanding of IOs' internal functioning is, therefore, both socially and politically relevant. Since IOs are first and foremost comprised of employees, understanding what sustains their organizational commitment and what type of work opportunities are likely to meet their expectations to allow them to perform meaningful work outcomes is thus crucial.

IOs are a particularly suitable field of research for organization scholars with regard to their distinctive features. In terms of "publicness" (Antonsen and Jorgensen 1997), they occupy an "intermediary" position in comparison with private and public organizations (Schemeil 2013). IOs are interesting comparative cases for public administration (Ege and Bauer 2013) and for business-oriented (Balding and Wehrenfennig 2011) research perspectives. Nevertheless, early calls to view them through an organizational lens (Ness and Brechin 1988) have only recently begun to be heeded (Haack and Mathiason 2010; Ellis 2010; Balding and Wehrenfennig 2011; Brechin and Ness 2013). However, with the exception of notable contributions (see several chapters in Reinalda 2013), IO employees are disregarded in this research agenda. Although the HR management of the United Nations is far from being a paragon of good practice (Beigbeder 2004) and is permanently 
under reform (Salomons 2004), little is known about the work preferences of international civil servants and what type of HR management practices sustain their willingness to make a difference by working in their organization. To fill this gap, two research questions inform this research: What work opportunities are related to the organizational commitment of international civil servants? Are these relationships mediated by perceived organizational support?

This research applies social exchange theory as its theoretical framework. Furthermore, it argues that characteristics shared by IOs contribute to shaping the work preferences of international civil servants. Therefore, we expect differentiated results compared with those of previous studies dealing with the work preferences of public- or private-sector employees. Therefore, this article makes two important contributions to the literature. First, it generates innovative empirical results with respect to international civil servants' preferences for work opportunities and their relationships with organizational commitment and perceived organizational support. Second, it better identifies the organizational levers - organizational factors that facilitate and enable employees to identify with their organization - that can be activated to favor the organizational commitment of international civil servants.

This article is organized as follows. Section one presents the theoretical framework and reviews the comparative literature on the preferences for work opportunities in the public and private sectors. Section two develops the research hypotheses on the basis of IOs' organizational specificities. Section three presents the research design and data measurement. Sections four and five discuss the empirical results, their theoretical 
meaning and their implications for HR management professionals. Before concluding, section six addresses some limitations of the research and explores areas for future research.

\section{Theoretical framework}

Social exchange theory is based on the idea that coordination and cooperation in organizations are a matter of reciprocal exchanges between employees and employers (Blau 1964; Homans 1961). Employers offer material and immaterial work conditions and opportunities to employees. In turn, employees reciprocate organizational efforts by working hard. In this vein, the employment relationship can be viewed as social or economic exchanges (Eisenberger, Fasolo, and Davis-LaMastro 1990; Gould-Williams and Davies 2005). Organizational structures can contribute to promoting and sustaining exchanges among individuals. The more individuals experience social exchange, the more willingly they commit themselves to the group or unit to which they belong. Two conditions must be met to generate commitment in social exchange: trust and affective ties (Lawler, Thye, and Yoon 2008). Favorable organizational treatment and work experiences create a feeling of organizational support among employees. Furthermore, perceived organizational support leads to positive work outcomes, such as organizational commitment.

\section{Organizational Commitment as a work-related outcome}

This research aims to identify the work opportunities that can explain why international civil servants are committed to their organizations. Presenting an exhaustive review of the previous literature on organizational commitment is out of the scope of this article. 
Nevertheless, the following paragraphs define the concepts and highlight some key results to justify the use of such a dependent variable in our research model.

Crewson (1997) presents a precise and clear definition of organizational commitment "as being an individual identification with and involvement in an organization. $\mathrm{He}$ emphasizes that it is made up of three distinct factors - a strong belief in and acceptance of the organization's values and aims, a significant willingness to work hard for one's organization and a desire to remain a member of it" (Giauque, Resenterra, and Siggen 2010, p. 189). Organizational commitment generally implies major professional loyalty and a deep identification with the organization (Steinhaus and Perry 1996). Therefore, this concept is of great interest because our research mainly aims to identify international civil servants' preferences for work opportunities that shape their identification with their organizations. The organizational commitment concept has been considered highly reliable in measuring human behavior in organized groups, especially when compared with other theoretical constructs, such as job satisfaction or job involvement (Jae Moon 2000).

\section{Work opportunities in different sectors}

Viewed through the lens of social exchange theory, organizational features do matter when studying individual preferences for work opportunities. Employees are embedded in an interactional relationship with the organization based on reciprocity. In these socialization processes, they incorporate such qualities as formal or informal norms, organizational values, or the general culture of their organization (Baba 1989; DiMaggio 1997; Meek 1988; Schein 1990). Therefore, even if employees join an organization with 
their own personal and professional values or expectations of the job, they are quickly confronted by organizational particularities and have to adapt to the organizational reality they face. Accordingly, in a co-production process, employees influence organizational characteristics, which in turn act as constraints or opportunities for them (Bouchikhi 1998; Kimberly and Bouchikhi 1995; Berger and Luckmann 1966). Organizational identity, that is, the central enduring and distinctive traits of an organization (see the seminal definition: Whetten 2006), is not neutral. Accordingly, previous research recurrently found significant differences in the preferences for work opportunities between organizations belonging to the public sector and those to the private sector.

To avoid the overly simplistic dichotomy between intrinsic and extrinsic motivations commonly found in comparative studies (Chen and Bozeman 2012), one can rely on the typology developed by Lyons, Duxbury, and Higgins (2006), who have identified five different work opportunities or preference orientations: extrinsic (i.e., benefits, job security, and good salary), intrinsic (i.e., intellectually stimulating work and interesting and challenging work), altruistic (i.e., helpful contribution to society and work that makes a difference), prestige ${ }^{\mathrm{i}}$ (i.e., authority, prestigious work, influence, and chance of promotion), and social (i.e., relations with co-workers or supervisor and friendly and supportive environment). A qualitative literature review showed that public-sector employees generally favor intrinsic work opportunities, whereas private-sector employees prefer extrinsic features. However, if extrinsic elements also matter to publicsector employees, then the difference between both categories is even more striking for altruistic and social work opportunities, which are clearly more prevalent among publicsector employees. Altruistic motives were extensively analyzed as part of the Public 
Service Motivation approach (Perry and Wise 1990). Within this frame, some studies included non-profit employees and volunteers for comparison. For them, altruistic work opportunities are also present and usually more prevalent than for government employees (Taylor 2010; Gabris and Simo 1995; Lyons, Duxbury, and Higgins 2006; Houston 2000; Steen 2008; Steijn 2008; Mann 2006; Light 2002; De Cooman et al. 2011). Moreover, preference for prestige work opportunities seems to be an attribute of private-sector workers.

No other comparative study similar to Lyons et al. (2006) including international civil servants was found. Therefore, our research represents a preliminary exploratory analysis that attempts to capture the most influential antecedents of organizational commitment for this category of workers. The research hypotheses elaborated in the next section are drawn from the few specific insights on international civil servants' preferences for work orientations.

\section{Research hypotheses on work opportunities in international}

\section{organizations}

\section{Extrinsic and intrinsic work opportunities}

To ensure a high degree of loyalty, neutrality, and integrity among employees, as referred to in the UN Charter (art. 101(3), United Nations 1945), and to attract highly skilled professionals, IOs offer high salaries (often untaxed), important benefits (health insurance and good pension plans) and compensation packages as another in-kind advantage for fieldwork abroad and relocation. The importance of missions, the specific goals delegated to these organizations, and specifically the high degree of competence required to fulfill 
them are likely to attract well-trained professionals greatly interested and challenged by the very nature of their jobs. Therefore, the extrinsic and intrinsic categories of work opportunities, although they may be considered as opposing (Frey and Jegen 2001), are likely to attract and retain individuals who value them since IOs are great for fulfilling both. According to recent research, there is a debate with respect to the unexpected effects of HR management practices focusing on extrinsic incentives, more specifically in public organizations (Frey, Homberg, and Osterloh 2013). Nevertheless, according to some economists, extrinsic incentives may play a role in motivation processes, at least in the short run (Bénabou and Tirole 2003). Thus, in this research, we start from the idea that extrinsic and intrinsic work opportunities are positively related to organizational commitment. The two related hypotheses are as follows:

H1: Satisfaction with extrinsic work opportunities increases organizational commitment and perceived organizational support.

H2: Satisfaction with intrinsic work opportunities increases organizational commitment and perceived organizational support.

\section{Altruistic and social work opportunities}

Well-paid and interesting jobs are not everything (Belle and Cantarelli 2014). Most individuals join IOs wanting to make a difference and to contribute to important societal issues. They join in order to fulfill idealistic goals as well, such as poverty eradication, promotion of social justice, realization of peace, and human rights advocacy. All these work opportunities are included under the altruistic category of work motives. Previous research on Public Service Motivation consistently demonstrated the importance of altruistic work opportunities in public organizations (Ritz, Brewer, and Neumann 2016), 
even more so in non-governmental or volunteer organizations, especially because jobs in such organizations usually have an important societal impact potential (van Loon et al. 2016). Recent comparative research demonstrated that public-sector employees expressed higher levels of public-service-oriented motives compared to their privatesector counterparts (Bullock, Stritch, and Rainey 2015). Furthermore, altruistic preferences have been found to be highly relevant (even more than for all pre-cited categories) among the employees of intergovernmental organizations. This is the case with civil servants of the European Commission (Vandenabeele and Ban 2009) and employees employed by IOs such as UN humanitarian agencies (Anderfuhren-Biget, Häfliger, and Hug 2013). On the organization side, IOs are responsible for devising and implementing international public policies alongside national bureaucracies (Biermann and Siebenhuner 2013; Joachim, Reinalda, and Verbeek 2007). They delegate mandates to solve global policy issues in all societal aspects of human activity: social, economic, humanitarian, ecological, and regulatory international politics. Consequently, these missions require from employees a genuine inclination for the fulfillment of "public interest," a pro-social work orientation, directed toward global problem-solving. With regard to the high degree of societal importance of missions that IOs engage in, we hypothesize the following:

H3: Satisfaction with altruistic work opportunities increases organizational commitment and perceived organizational support.

In previous research on international civil servants, social work opportunities were related to numerous positive work outcomes (Judge and Klinger 2007; Anderfuhren-Biget et al. 2010) and prevented negative job outcomes, such as stress or burnout (Karasek and 
Theorell 1990; Maslach, Schaufeli, and Leiter 2001; Bakker and Demerouti 2007). Therefore, social support and positive relationships with co-workers and supervisors are important antecedents of well-being at work. In this vein, we assume the following: H4: Satisfaction with social work opportunities increases organizational commitment and perceived organizational support.

\section{Mediation effect of perceived organizational support}

In accordance with the social exchange framework, individuals who encounter positive work opportunities in their organization reciprocate organizational efforts by committing harder to their organization and to their work. This process can be explained by the fact that employees feel that their organization cares about them. When satisfied by work conditions, employees also perceive support from their organization. Put another way, perceived organizational support may lead to organizational commitment. Indeed, previous literature found that perceived organizational support is positively associated with affective commitment and mediates positive relationships among organizational rewards, procedural justice, supervisor support, and affective commitment (Rhoades, Eisenberger, and Armeli 2001). Similarly, perceived organizational support is likely to mediate the association of the different work opportunities investigated in the present research with organizational commitment, as postulated in the last hypothesis of the theoretical framework (see Figure 1 below):

H5: Perceived organizational support mediates the relationship between work opportunities and organizational commitment.

[Figure 1 here] 


\section{Data and measurement}

\section{Sample}

This article relies on original data collected from four specialized and unique agencies of the United Nations system: Office of the High Commissioner on Human Rights (OHCHR), United Nations Refugee Agency (UNHCR), International Telecommunication Union (ITU), and Universal Postal Union (UPU). The first two agencies operate in the humanitarian domain: OHCHR deals with human rights advocacy and UNHCR provides operational support in cases of emergency crises. ITU and UPU are technical and normative organizations. Aside from the policy domain in which they operate, the size and localization of these IOs also differs. UNHCR is headquartered in Geneva and employs more than 7,700 permanent employees, among which $80 \%$ are deployed in the field. OHCHR is smaller with about 1,100 employees at the time of the data collection, and most of its work is performed at its headquarters in Geneva and New York as well as in several country or regional offices. UPU, the oldest intergovernmental organization, is located in Bern and employs about 250 employees. Most of its activities deal with technological and market challenges facing the postal industry, and it aims to improve the postal sector in less developed countries. The ITU is a particular case of a technical intergovernmental IO as it is based on a unique public-private partnership: more than 800 private entities operating in the information and communications technologies industry are part of its membership. The 700 employees located at the Geneva headquarters follow its mandate to create a seamless global communications system by, among others, brokering agreements on technologies and services and allocating global resources such as radio-frequency spectrum and satellite orbital frequencies. 
Having obtained the consent of the general directors and HR departments, a Web-based survey was made available to all categories of employee. Individual respondents were informed about the purpose of the study, encouraged to participate, and assured of data confidentiality. They were free to participate or not. They did not receive any compensation for participating in the written survey. The questionnaires were anonymous and sent directly to the participants. This procedure allowed the researchers to control the conditions under which the questionnaires were completed and to reduce the opportunities for shared responses (Thomas and Smith 2003). In addition, we informed the participants that there were no right or wrong answers, and encouraged them to answer all questions based on their experience and perceptions. These approaches can reduce method biases (Podsakoff et al. 2003). At the end of this process, 1,769 valid questionnaires were returned. Depending on the capacity of the HR department to involve employees in the research and on the degree of decentralization, the response rates ranged from acceptable ( $14 \%$ for UNHCR and $25 \%$ for ITU) to very good ( $35 \%$ for OHCHR and $44 \%$ for UPU). To treat appropriately the missing values, our regression models used the pairwise deletion method. Table 1 summarizes the sociodemographic characteristics of the surveyed population. According to the data provided by the participating HR services, the survey samples collected accurately represented the employee characteristics of each organization. However, note that we observed a slight overrepresentation of younger employees and entry-level professional staff (P1-P3) at ITU, professionals (P1-P5) at UPU, and higher categories (P1-P5 and D) and women at UNHCR, where the general service staff $(G)$ are slightly underrepresented. 
[Table 1 here]

\section{Measurement of the variables}

The empirical variables consisted of items taken from attested scales with response options on a five-point Likert-type scale. Most of the variables were computed as summative indexes using several items (Appendix 1). After performing factor analyses for the related items, reliability tests were applied (Cronbach's alpha). According to the usual statistical criteria, their internal reliability was very good for most variables.

The dependent variable Organizational Commitment (OC, $\alpha=.649)$ was measured with a three-item equation developed in previous research (Benkhoff 1997; Vandenabeele 2009). An example item is as follows: "I am proud to tell others that I am part of this organization." Even if the Cronbach's alpha was not higher than the usual threshold (0.7), it could still be considered acceptable (Loewenthal 2004).

Several variables of work opportunities were included as independent variables in the present study. The participants were asked to answer if they were satisfied with the different work opportunities their organization had provided them. Our procedure is relatively similar to that of previous research that measured employee satisfaction in the different facets of their work (Spector 1985, 1994; Daley and Vasu 2005). The variables of different work opportunities included in the research are as follows:

Extrinsic Work Opportunities (EWO, $\alpha=.813$ ) are mainly related to extrinsic nonmonetary and monetary work opportunities. Five items were developed to measure the 
extent to which our respondents were satisfied with their income, pay rises, benefits (pension plans, holidays, etc.), and job security.

Intrinsic Work Opportunities (IWO, $\alpha=.861)$ measure intrinsic non-monetary work opportunities. Five items were developed to capture the extent to which the respondents were satisfied with the offered training programs and opportunities to participate or suggest improvements. These items are related to task meaningfulness, work responsibility and autonomy, and professional growth.

The variable Altruistic Work Opportunities (AWO, $\alpha=.837)$ was developed according to the background of the Public Service Motivation measurement, as developed by Perry (1996) and Kim (2009). It is composed of six items designed to measure the extent to which the respondents expect to contribute to society in the context of their work.

Social Work Opportunities (SWO, $\alpha=.878$ ) are related to the opportunities offered by the work context with respect to social relationships. This variable is composed of six items measuring the extent to which the respondents are satisfied with the work atmosphere with their co-workers or supervisor.

The variable Perceived Organizational Support (POS, $\alpha=.893)$ is the mediator in our theoretical framework (see Figure 1 above) and is measured using five items already tested in previous research (Eisenberger, Fasolo, and Davis-LaMastro 1990; Su, Baird, and Blair 2009). 
Several control variables constitute the baseline model for the empirical test of the research hypotheses. This first set contains the usual individual features (i.e., gender, age, educational level, and organizational tenure) and the distinctive features of IO work, such as expatriation status or work location (i.e., headquarters vs. fieldwork).

\section{Statistical Procedure}

All statistical analyses were performed with SPSS version 22. To confirm the quality of the dataset, tests required for multiple linear regressions were conducted. The assumption of normality was upheld, and all the studied variables fell within the suggested range (skewness of less than 2 and kurtosis of less than 7). Thus, the dataset was examined to assess multicollinearity. According to statistical standards (bivariate correlations lower than 0.900 , tolerance and VIF statistics), all variables had discriminant validity (John and Benet-Martinez 2000), and all indices fell within the acceptable range (Carricano and Poujol 2008). To provide descriptive evidence, the means were computed and assessed. Bilateral correlations were performed to evaluate the intensity of the relations (Appendix 2). Multiple regressions were performed to determine the relative associations between independent variables and organizational commitment. Model 1 tested for whether the control variables add unique variance, and Model 2 integrated the independent variables of interest.

The mediating effect of perceived organizational support was assessed according to Baron and Kenny's standard (1986). Mediation occurs when significant correlations exist between work opportunities and perceived organizational support (path A), perceived organizational support affects organizational commitment (path B) and the differences in 
work opportunities are significantly related to differences in organizational commitment (path $\mathrm{C}$ ). When path $\mathrm{A}$ and path $\mathrm{B}$ are controlled for, the previously significant relationships between work opportunities and organizational commitment (path C) disappear (Schott and Pronk 2014, 14). As complete mediation is unlikely to occur in this type of research, we used the Sobel test (Preacher and Leonardelli 2001) and a Z-score > 1.95 as cut-off criteria to indicate partial mediation.

\section{Empirical results}

\section{Preliminary descriptive results}

In this section, we first highlight the preliminary descriptive results before discussing the effect on the main variables. All mean levels are above the theoretical average of 2.5 (Appendix 2). Organizational commitment is relatively high (3.88), thus indicating that our respondents were highly committed. With respect to perceived organizational support, the mean level is low (2.73), thus demonstrating that the respondents were not always satisfied with their organization's efforts in providing organizational support. The result shows preliminary evidence of the relative importance of work opportunities for the studied population. The work opportunities are as follows in descending order: altruistic (4.01), social (3.48), extrinsic (2.98), and intrinsic (2.71).

The correlations analysis provides important findings. All the work opportunities variables are significantly correlated $(\mathrm{p}<.001)$ with organizational commitment according to the following patterns: altruistic $(r=.581)$, social $(r=.313)$, intrinsic $(r=$ $.277)$, and extrinsic $(r=.259)$ work opportunities. These variables are also highly and significantly $(\mathrm{p}<.001)$ related to perceived organizational support. Note that perceived 
organizational support is also significantly related to organizational commitment $(\mathrm{r}=$ $.431 ; \mathrm{p}<.001$ ); therefore, the mediation effects have to be taken into account (path B in the theoretical framework). In sum, the results from the descriptive statistics support the five research hypotheses. However, to provide sound empirical findings, the relative weights of work opportunities should be considered in explaining organizational commitment and perceived organizational support.

In analyzing the correlations among the control variables, the respondents who work in the field or who move frequently between the field and headquarters tend to declare a high level of organizational commitment. Whereas local workers declare a high level of organizational commitment, expatriates report a low level of organizational commitment. The same trends can be found with perceived organizational support. Being a local employee and having the opportunity to work contractually in the field rather than always being at the headquarters are two characteristics associated with organizational commitment and perceived organizational support.

\section{Regression models results}

In Model 1 (see Table 2), four control variables are significantly related to perceived organizational support (path A). Male respondents are more prone to declare higher levels of perceived organizational support than their female counterparts. Moreover, international civil servants with a shorter tenure are more likely to declare a higher level of perceived organizational support. Local employees and those working in the field or who move frequently between the field and headquarters also report a higher level of 
perceived organizational support. Model 1 accounts for a small proportion of the variance of perceived organizational support (10.9\%).

Model 2 indicates that the same control variables are associated with perceived organizational support when the variables of work opportunities are introduced into the equation. Moreover, all the variables of work opportunities are significantly related to perceived organizational support in various proportions: extrinsic $\left(\mathrm{r}=.290^{* * *}\right)$, social $(\mathrm{r}$ $\left.=.221^{* * *}\right)$, intrinsic $\left(\mathrm{r}=.164^{* * *}\right)$, and altruistic $\left(\mathrm{r}=.157^{* * *}\right)$ work opportunities. They all have a positive effect on perceived organizational support. The addition of these variables substantially improves the variance explained in the equation $\left(\Delta \mathrm{R}^{2}=.358\right)$. In other words, extrinsic, social, intrinsic, and altruistic work opportunities clearly contribute to providing a sense of organizational support among the survey respondents.

[Table 2 here]

In explaining the antecedents of organizational commitment (path C), Model 3 (see Table 3) shows that local employees and international civil servants who work mainly in the field or move frequently between the field and headquarters are likely to declare a high level of organizational commitment. This result is similar to the one related to perceived organizational support presented above. However, Model 3 explains only a small proportion of organizational commitment variance (5.9\%). Model 4, which includes the work opportunities variables, delivers interesting results. Three out of four independent variables are significantly and positively related to organizational commitment. Altruistic work opportunities are by far the most important antecedent of organizational 
commitment $\left(\mathrm{r}=.511^{* * *}\right)$, and social $\left(\mathrm{r}=.161^{* * *}\right)$ as well as extrinsic $\left(\mathrm{r}=.127^{* *}\right)$ work opportunities are also associated with organizational commitment. By contrast, the intrinsic work opportunities variable is not significantly related to organizational commitment. The variables entered in this analysis (Model 4) explain approximately $41 \%$ of the variation of organizational commitment.

[Table 3 here]

Following mediation analysis standards, only the independent variables that are significantly related to both perceived organizational support and organizational commitment should be included in the mediation models (see Table 4). The inclusion of perceived organizational support clearly reduces the effect of altruistic and social work opportunities on organizational commitment, whereas the effect of extrinsic work opportunities simply disappears after the inclusion of perceived organizational support in the equation. According to the results of the Sobel test, perceived organizational support partially mediates the relationship between altruistic $(Z=4.04 ; p<.000)$ and $\operatorname{social}(Z=$ $5.88 ; p<.000)$ work opportunities and organizational commitment. In addition, perceived organizational support fully mediates the association between extrinsic work opportunities $(Z=6.68 ; p<.000)$ with organizational commitment (see Table 5).

[Table 4 here]

[Table 5 here] 
Table 6 summarizes these findings by showing how far the empirical results support the research hypotheses.

[Table 6 here]

\section{Discussion}

Before examining the work opportunities that increase international civil servants' commitment to their organization and work, we briefly discuss the control variables that also significantly positively affect organizational commitment. The organizational levers that can be activated to favor organizational commitment among international civil servants are then identified. In the context of this article, organizational levers are mainly related to work opportunities and can be defined as organizational factors that facilitate and enable employees to identify with their organization.

\section{Variables affecting organizational commitment}

Even if women find breaking the glass ceiling to reach top positions difficult, their proportion among international civil servants is increasing in the IOs of the UN system (Weiss 2010). That said, in the surveyed population, male employees are more inclined than women to be satisfied with what their organizations provide in terms of organizational support, be it related to values, extrinsic incentives, intrinsic opportunities, or even in terms of social experiences. Accordingly, this research underlines that much more efforts have to be developed to promote women in IOs and provide them with fulfilling work opportunities. Thus, progress must be made to ensure women's commitment and engagement in IOs. 
Work location is also an important explanatory factor of perceived organizational support and organizational commitment in IOs. Respondents doing fieldwork or those who move frequently between the field and headquarters are more likely to declare a high level of perceived organizational support and organizational commitment. Again, the relevant IO's work specificities explain this finding. According to the mobility principle (see (art. 1.2(c), Staff Regulations, United Nations 2009), employees can be assigned to any of the activities or offices of the United Nations depending on the organizational demand. Therefore, in specific IOs (one of which is part of this research's sample), an additional rotation principle required of international civil servants is that employees experience both field and office work duties (Weiss 2010, 2012). Employees know these features when entering the UN system. Therefore, it is not striking that mobility and experiences in the field are related to organizational identification and involvement. Field missions are crucial defining traits of the professional identity of international civil servants, particularly for humanitarian workers (Dauvin and Siméant 2002; Fresia 2009). Consequently, this research can only encourage HR managers in IOs to develop supportive HR policies to achieve this prerequisite, the deficit of which can threaten the work-life balance and work well-being of their employees.

\section{Comparing international organizations employees with their national public- and private-sector counterparts}

The hybrid nature of IOs is reflected in the work opportunity preferences of their employees compared with their public- or private-sector counterparts. To summarize, the preference for the intrinsic and altruistic categories is consistently reported to be a definite 
feature of national public-sector employees, whereas private-sector employees value more extrinsic and prestige work opportunities. In the present study, satisfaction with altruistic, social, and, to a lesser extent, extrinsic work opportunities are important antecedents of organizational commitment among respondents and could be considered, therefore, as organizational levers that enable international civil servants to identify with their organization. Altruistic work opportunities appear to be the first predictor of organizational commitment, which is not surprising given that the UN system was created on the Enlightenment philosophy of serving humanitarian values as they are defined in the UN Charter and further detailed in the Universal Declaration of Human Rights (United Nations 1945, 1948). Individuals joining UN agencies are sincerely convinced by these values and believe that their work will make a difference in and positively benefit humanity. This phenomenon has been reported among aid practitioners (Fechter 2012; de Jong 2011) and humanitarian workers (Vaux 2001). Altruistic work opportunities has been extensively studied in public administration scholarship with respect to Public Service Motivation (for an overview of this research perspective, see Perry and Hondeghem 2008). This concept captures a special type of other-oriented motivation that is based on the realization of public service and collective values. Empirical evidence showing that Public Service Motivation is one of the most decisive factors of positive job attitudes and behaviors for national public-sector employees abounds (Anderfuhren-Biget et al. 2010; Bright 2008; Kamdron 2005; Leisink and Steijn 2009; Taylor 2007; Taylor and Taylor 2011; Wright and Christensen 2009). The close relationship of Public Service Motivation with organizational commitment and person-organization fit in the public sector has also been acknowledged (Christensen and Wright 2011; Wright and Pandey 2008). Therefore, this article contributes to the advancement of the Public Service 
Motivation perspective by demonstrating that it is also the case for international civil servants working within the United Nations complex. If organizational commitment increases when international civil servants can benefit from work conditions that allow them to experience concretely altruistic work opportunities, then HR practitioners should do their best to design job and work tasks that sustain this willingness to make a difference for the good of the humanity, or at least to not harm it. Avoiding red tape, which constrains concrete work in the international realm (Dar and Cooke 2008; Gulrajani 2011; Natsios 2010), providing room to maneuver, and giving international civil servants autonomy from bureaucratic overburdening may be some of the right paths to follow. In the scientific literature, the dark side of (international) bureaucracy is consistently associated with negative work outcomes, such as job resignation, dissatisfaction at work, and high turnover (Bozeman 2000; DeHart-Davis and Pandey 2005; Giauque, Anderfuhren-Biget, and Varone 2013; Pandey and Kingsley 2000; Scott and Pandey 2005), which in turn have detrimental effects on organizational commitment. It would be harmful for organizational efficiency to not provide the best possible conditions for human assets. IOs must also valorize the missions they manage, particularly if these missions are related to altruistic motives.

Satisfaction with extrinsic work opportunities is also associated, to a lesser extent, with organizational commitment. Extrinsic incentives, specifically in IOs, tend to be more valued by employees than intrinsic ones. In this regard, international civil servants seem to share some preferences for work opportunities with their private-sector counterparts, who are likely to prefer extrinsic rather than intrinsic rewards. By contrast, this is not the case for national public-sector employees who are more likely to desire intrinsic non- 
monetary work opportunities (Bright 2009). The mixed findings of the present research confirm that IOs are hybrid organizations; that hybridity is reflected in the work conditions preferences of international civil servants. Therefore, the specificities of IOs as work environments provide a sound explanation for these mixed findings.

\section{Overriding cultural heterogeneity?}

In this research, we also found that social work opportunities are an important antecedent of organizational commitment. Having good social relationships with colleagues and supervisors is important in order to enjoy the work environment. Working in a good social atmosphere may favor trust and social ties, which are two important dimensions in social exchange theory. A trustworthy work climate and satisfactory social relationships, in one phrase, "social support," have been consistently found to be antecedents of positive work outcomes and may also mitigate negative work outcomes, such as stress, turnover intention, or burn out (Giauque, Anderfuhren-Biget, and Varone 2016; Johnson and Hall 1988). Therefore, this research confirms previous results with respect to the importance of social relationships and social support available to employees. However, a high degree of cultural diversity differentiates IOs from organizations in any other sector. The surveyed UN agencies' employees seemed to be at ease in their work environment. This could be due to homogenous values, for example, cosmopolitism and transnationalism (Dezalay 2004), which seem to override cultural heterogeneity. However, HR managers working in IOs should develop a positive relational climate that favors the development of a positive relationship among employees all along the hierarchical ladder and from all cultural backgrounds. 


\section{Methodological limitations and future research}

In accordance with the theoretical framework, the empirical findings confirm the importance of work conditions and organizational support in explaining organizational commitment. Indeed, as outlined above, work opportunities in IOs are all significantly related to perceived organizational support. Moreover, perceived organizational support partially mediates the relationships between altruistic and social work opportunities and organizational commitment, and it completely mediates the association between extrinsic incentives and organizational commitment. These findings support social exchange theory. Favorable work experiences, such as being satisfied with work opportunities, may create a feeling of organizational support. In turn, perceived organizational support is built according to favorable work experiences that employees may encounter in their organization. Therefore, the empirical results suggest that satisfactory organizational treatment may create favorable conditions that contribute to building a positive relationship between employees and their organization.

As with all empirical research, this article has several methodological limitations. First, as our data are cross-sectional in nature, identifying strong causal relationships between our variables remains difficult. Nevertheless, if we follow DeHart-Davis et al.'s (2015) argument, then theoretical reasoning is important and may provide guidance when it comes to deal with causal relationships. According to theories reviewed previously, our assumption is that satisfaction with work opportunities precedes perceived organizational support and organizational commitment. Our results are consistent with the theoretical argument, even if we acknowledge that future research will be useful to shed light on the relationships we tested in the present study. 
Second, the one-sided methodology (i.e., a self-report survey to collect predictor and outcome variables) adopted in the present study can result in common method biases, as correlations arise because of hidden systematic features that support the measured variables (Podsakoff et al. 2003). This methodological strategy may inflate the reported effect sizes, and it is a recognized drawback of fit studies (Kristof-Brown et al. 2005, 293). Therefore, according to the reported effect sizes and significance changes comparing various models, predictors may interact with one another.

Another drawback of cross-sectional data is related to the moment of data collection. Time is an important variable in the study of work outcomes. Indeed, IOs are currently confronting new political and managerial pressures. Reforms are taking place, and it is only a matter of time before they affect the work life of employees.

Finally, the investigated IOs are active in different policy domains. In this research, the respondents working in humanitarian IOs represent $83.1 \%$ of the overall sample, and those working in technical IOs represent $16.9 \%$ of the sample. To compare the two types of organizations (humanitarian vs. technical IOs), we conducted separate hierarchical regression analyses on organizational commitment and perceived organizational support according to our two specific populations. The results show that altruistic, social, and extrinsic work opportunities are associated with organizational commitment in humanitarian IOs, whereas only altruistic work opportunities are significantly related to organizational commitment in technical IOs. Furthermore, all work opportunities variables are associated with perceived organizational support in the humanitarian IOs 
sample, whereas only extrinsic and altruistic work opportunities are positively and significantly related to perceived organizational support in the technical IOs sample. These results suggest that differences may be identified according to the policy domains of specialized UN agencies.

All these methodological limitations may lead to new research perspectives that we can list below. First, interaction effects between different work opportunities may contribute to better identify organizational levers, which could help promote organizational commitment in IOs. Second, IOs have been mainly studied in the scientific literature to date as "black boxes." This article tries to open this black box, but future research should be developed to better understand the potential impact on employee commitment of the numerous organizational reforms currently being undertaken in UN agencies and other IOs. For instance, it could be of great interest to assess the human consequences of "cutbacks" management. As regards to our own research, the work opportunities variables measured here may evolve with the development and implementation of new managerial reforms. Future research with longitudinal data will be valuable in this regard. Third, enriching the statistical survey by a qualitative investigation would increase our understanding of the sense that international civil servants give to their work experiences, that is, whether they are satisfactory or unsatisfactory. We therefore encourage future qualitative research on IOs. Finally, the present study identifies differences between humanitarian and technical UN agencies in explaining organizational commitment or perceived organizational support. This finding clearly suggests that policy domains of specialized IOs may influence employees' behaviors and expectations. This variable 
could be analyzed more precisely in future studies comparing IOs with very different missions and competences.

\section{Conclusion}

The present study examines the link between different types of work opportunities and organizational commitment as well as the perceived organizational support among employees working in four UN agencies. It offers several important contributions. First, it uses primary data about the work preferences and attitudes of international civil servants belonging to the UN system. Therefore, it helps to better identify the organizational levers that can be activated to promote organizational commitment among this specific population. Second, the empirical findings confirm the accuracy of social exchange theory. When employees perceive satisfactory treatment from their organization, they are likely to develop feelings of obligation toward their organization. These social exchange processes rely on different pillars, such as respondents' satisfaction with altruistic, social, and extrinsic work opportunities. In addition, the perceived organizational support is an important mediation process that explains organizational commitment. Third, this research points out that organization-specific traits of IOs matter when investigating work preferences and commitment. Even if some authors have highlighted the blurred boundaries among different types of organization (non-profit, forprofit, public, and private) (Bromley and Meyer 2017), thus suggesting that distinguishing among these organizations has become increasingly difficult, the findings of the present study clearly point out the importance of organizational traits in managing employees. At the organizational macro level, organizations are becoming more identical. Conversely, at the organizational micro level, organizational special features actually do 
matter. This finding clearly confirms that HR management is not only dependent on organizational characteristics but also on work activities. However, in explaining employees' attitudes and preferences, diversity rather than homogeneity remains important. The findings of the present study underline not only the hybrid nature of IOs but also their distinctive characteristics. International civil servants who are satisfied with altruistic work opportunities are likely to declare a high level of organizational commitment. They tend to become like public-sector employees in national administrations. Conversely, international civil servants who are satisfied with extrinsic work opportunities are also likely to declare a high level of organizational commitment. This finding is clearly not consistent with that of previous research with respect to publicsector employees' work preferences (Bright 2009). In sum, international civil servants differ from their public- and private-sector counterparts in explaining their preferences for work opportunities. For them, IOs are not only excellent places to be employed in terms of values and social relationships, but they also provide interesting extrinsic incentives. Entering the black box that constitutes IOs and conducting research on international civil servants are areas of study that have been neglected to date and are worth examining since they may contribute to the greater understanding of both. Therefore, further research on IOs is needed to elucidate the link between their specific features and the attitudes and behaviors of international civil servants.

\footnotetext{
${ }^{\mathrm{i}}$ This dimension is not investigated in this research because of the lack of empirical data.
} 


\section{Bibliography}

Anderfuhren-Biget, S, Ursula Häfliger, and S Hug. 2013. The values of staff in international organizations. In Routledge Handbook of International Organizations, edited by Bob Reinalda, 270-283. New York: Routledge.

Anderfuhren-Biget, S, F Varone, D Giauque, and A Ritz. 2010. Motivating Employees of the Public Sector: Does Public Service Motivation Matter? International Public Management Journal 13 (3): 213-246.

Antonsen, Marianne, and Torben Beck Jorgensen. 1997. The "Publicness" of Public Organizations. Public Administration 75 (2): 337-357.

Baba, Marietta L. 1989. Organizational Culture: Revisiting the Small-Society Metaphor. Anthropoloy of Work Review 10 (3): 7-10.

Bakker, Arnold B., and Evangelia Demerouti. 2007. The Job Demands-Resources model: State of the art. Journal of Managerial Psychology 22 (3): 309-328.

Balding, Christopher, and Daniel Wehrenfennig. 2011. An Organizational Theory of International Institutions. Journal of International Organization Studies 2 (1): 7-27.

Baron, Reuben M., and David A. Kenny. 1986. The moderator-mediator variable distinction in social psychological research: Conceptual, strategic, and statistical considerations. Journal of personality and social psychology 51 (6): 1173-1182.

Beigbeder, Yves. 2004. Fraud, Corruption, and United Nations Culture. In Rethinking international organizations: pathology and promise, edited by Dennis Dijkzeul and Yves Beigbeder, 166192. New-York: Berghahn Books.

Belle, Nicola, and Paola Cantarelli. 2014. Monetary Incentives, Motivation, and Job Effort in the Public Sector. Review of Public Personnel Administration 35 (2): 99-123. doi: 10.1177/0734371x13520460. Bénabou, Roland, and Jean Tirole. 2003. Intrinsic and Extrinsic Motivation. The Review of Economic Studies 70 (3): 489-520.

Benkhoff, Birgit. 1997. Disentangling Organizational Commitment. Personnel Review 26 (1/2): 114-131.

Berger, Peter L., and Thomas Luckmann. 1966. The Social Construction of Reality: A Treatise in the Sociology of Knowledge. Garden City, NY: Anchor Books. 
Biermann, Frank, and Bernd Siebenhuner. 2013. Problem Solving by International Bureaucracies: the Influence of International Secretariats on World Politics. In Routlegde Handbook of International Organizations, edited by Bob Reinalda, 149-161. New York: Routledge.

Blau, Peter Michael. 1964. Exchange and power in social life. New York: Wiley.

Bouchikhi, Hamid. 1998. Living with and building on complexity: A constructivist perspective on Organizations. Organization 5 (2): 217-232.

Bozeman, Barry. 2000. Bureaucracy and Red Tape. Upper Saddle River, NJ: Prentice Hall.

Brechin, Steven R., and Gayl D. Ness. 2013. Looking Back at the Gap: International Organizations as Organizations Twenty-Five Years Later. Journal of International Organization Studies 4 (2): 14-39.

Bright, Leonard. 2008. Does Public Service Motivation Really Make a Difference on the Job Satisfaction and Turnover Intentions of Public Employees? The American Review of Public Administration 38 (2): $149-166$.

Bright, Leonard. 2009. Why Do Public Employees Desire Intrinsic Nonmonetary Opportunities? Public Personnel Management 38 (3): 15-37.

Bromley, Patricia, and John W. Meyer. 2017. "They Are All Organizations”: The Cultural Roots of Blurring Between the Nonprofit, Business, and Government Sectors. Administration \& Society 49 (7): 939-966. doi: doi:10.1177/0095399714548268.

Bullock, Justin B., Justin M. Stritch, and Hal G. Rainey. 2015. International Comparison of Public and Private Employees' Work Motives, Attitudes, and Perceived Rewards. Public Administration Review 75 (3): 479-489. doi: 10.1111/puar.12356.

Carricano, Manu, and Fanny Poujol. 2008. Analyse de données avec SPSS. Paris: Pearson Education.

Chen, Chung-An, and Barry Bozeman. 2012. Understanding Public and Nonprofit Managers' Motivation

Through the Lens of Self-Determination Theory. Public Management Review 15 (4): 584-607. doi: $10.1080 / 14719037.2012 .698853$.

Christensen, Robert K., and Bradley E. Wright. 2011. The Effects of Public Service Motivation on Job Choice Decisions: Disentangling the Contributions of Person-Organization Fit and Person-Job Fit. Journal of Public Administration Research and Theory 21 (4): 723-743. doi: 10.1093/jopart/muq085. 
Crewson, Philip E. 1997. Public-Service Motivation: Building Empirical Evidence of Incidence and Effect. Journal of Public Administration Research and Theory 7 (4): 499-518.

Daley, Dennis M., and Michael L. Vasu. 2005. Supervisory perceptions of the impact of public sector personnel practices on the achievement of multiple goals. Putting the strategic into human resource management. American Review of Public Administration 35 (2): 157-167.

Dar, Sadhvi, and Bill Cooke. 2008. The new development management: Critiquing the dual modernization: Zed Books.

Dauvin, Pascal, and Johanna Siméant. 2002. Le travail humanitaire: les acteurs des ONG, du siège au terrain. (Humanitarian work: NGO's actors in headquarters and field missions). Paris: Presses de sciences po.

De Cooman, Rein, Sara De Gieter, Roland Pepermans, and Marc Jegers. 2011. A cross-sector comparison of motivation-related concepts in for-profit and not-for-profit service organizations. Nonprofit and voluntary sector quarterly 40 (2): 296-317.

de Jong, Sara. 2011. False Binaries: Altruism and Selfishness in NGO Work. In Inside the Everyday Lives of Development Workers: The Challenges and Futures of Aidland, edited by A-M. Fechter and H. Hindman, 21-40. Sterling: Kumarian Press.

DeHart-Davis, Leisha, Randall S. Davis, and Zachary Mohr. 2015. Green Tape and Job Satisfaction: Can Organizational Rules Make Employees Happy? Journal of Public Administration Research and Theory 25 (3): 849-876. doi: 10.1093/jopart/muu038.

DeHart-Davis, Leisha, and Sanjay K. Pandey. 2005. Red Tape and Public Employees: Does Perceived Rule Dysfunction Alienate Managers? Journal of Public Administration Research and Theory 15 (1): 133-148.

Devin, Guillaume, and Marie-Claude Smouts. 2011. Les organisations internationales. Paris: Armand Colin. Dezalay, Yves. 2004. Les courtiers de l'international. Actes de la recherche en sciences sociales 151-152 (1): 435.

DiMaggio, Paul. 1997. Culture and Cognition. Annual Review of Sociology 23: 263-287.

Ege, Jörn, and M.W. Bauer. 2013. International Bureaucracies from a Public Administration and International Relations Perspective. In Routledge Handbook of International Organizations, edited by B. Reinalda, 299-311. New York: Routledge. 
Eisenberger, Robert, Peter Fasolo, and Valerie Davis-LaMastro. 1990. Perceived Organizational Support and Employee Diligence, Commitment, and Innovation. Journal of Applied Psychology 75 (1): 5159. doi: Doi 10.1037//0021-9010.75.1.51.

Ellis, David C. 2010. The Organizational Turn in International Organization Theory. Journal of International Organization Studies 1 (1): 11-27.

Fechter, Anne-Meike. 2012. The Personal and the Professional: Aid workers' relationships and values in the development process. Third World Quarterly 33 (8): 1387-1404. doi: $10.1080 / 01436597.2012 .698104$.

Fresia, Marion. 2009. Une élite transnationale: la fabrique d'une identité professionnelle chez les fonctionnaires du Haut Commissariat des Nations Unies aux Réfugiés. Revue européenne des migrations internationales 25 (3): 167-190.

Frey, Bruno S, and Reto Jegen. 2001. Motivation crowding theory. Journal of Economic Surveys 15 (1): 589 611.

Frey, Bruno S., Fabian Homberg, and Margit Osterloh. 2013. Organizational Control Systems and Pay-forPerformance in the Public Service. Organization Studies 34 (7): 949-972. doi: Doi $10.1177 / 0170840613483655$.

Gabris, Gerald T., and Gloria Simo. 1995. Public Sector Motivation as an Independent Variable Affecting Carreer Decision. Public Personnel Management 24 (1): 33-51.

Giauque, David, Simon Anderfuhren-Biget, and Frédéric Varone. 2013. Stress Perception in Public Organisations: Expanding the Job Demands-Job Resources Model by Including Public Service Motivation. Review of Public Personnel Administration 33 (1): 58-83. doi: $10.1177 / 0734371 \times 12443264$.

Giauque, David, Simon Anderfuhren-Biget, and Frédéric Varone. 2016. Stress and turnover intents in international organizations: social support and work-life balance as resources. The International Journal of Human Resource Management: 1-23. doi: $10.1080 / 09585192.2016 .1254105$.

Giauque, David, Fabien Resenterra, and Michaël Siggen. 2010. The relationship between HRM practices and organizational commitment of knowledge workers. Facts obtained from Swiss SMEs. Human Resource Development International 13 (2): 185-205. 
Gould-Williams, Julian, and Fiona Davies. 2005. Using social exchange theory to predict the effects of HRM practice on employee outcomes. Public Management Review 7 (1): 1-24.

Gulrajani, Nilima. 2011. Transcending the Great Foreign Aid Debate: managerialism, radicalism and the search for aid effectiveness. Third World Quarterly 32 (2): 199-216. doi: $10.1080 / 01436597.2011 .560465$.

Haack, Kirsten, and John R. Mathiason. 2010. International Organization Studies - A New Frontier for Scholarship. Journal of International Organization Studies 1 (1): 5-10.

Homans, George. 1961. Social behavior. New York: Harcourt, Brace, and World.

Houston, David J. 2000. Public-Service Motivation: A Multivariate Test. Journal of Public Administration Research and Theory 10 (4): 713-727.

Jae Moon, M. 2000. Organizational commitment revisited in new public management. Public Performance \& Management Review 24 (2): 177-194.

Joachim, Jutta, Bob Reinalda, and Bertjan Verbeek. 2007. International organizations and implementation: enforcers, managers, authorities? New York: Routledge.

John, Oliver P., and Veronica Benet-Martinez. 2000. Measurement: Reliability, construct validation, and scale construction. In Handbook of research methods in social psychology, edited by Harry T. Reis and Charles M. Judd, 339-369. New York: Cambridge University Press.

Johnson, Jeffrey V., and Ellen M. Hall. 1988. Job strain, work place social support, and cardiovascular disease: a cross-sectional study of a random sample of the Swedish working population. American Journal of Public Health 78 (10): 1336-42.

Judge, Timothy A., and Ryan Klinger. 2007. Job Satisfaction. Subjective Well-Being at Work. In The Science of Subjective Well-Being, edited by Michael Eid and Randy J. Larsen, 393-413. New York: Guilford Publications.

Kamdron, Tiiu. 2005. Work motivation and job satisfaction of Estonian higher officials. International Journal of Public Administration 28: 1211-1240.

Karasek, Robert A., and Töres Theorell. 1990. Healthy work: stress, productivity, and the reconstruction of working life. New York: Basic Books.

Kim, S. 2009. Revising Perry's Measurement Scale of Public Service Motivation. American Review of Public Administration 39 (2): 149-163. 
Kimberly, John R., and Hamid Bouchikhi. 1995. The dynamics of organizational development and change: How the past shapes the present and constrains the future. Organization Science 6 (1): 9-19.

Lawler, Edward J., Shane R. Thye, and Jeongkoo Yoon. 2008. Social exchange and micro social order. American Sociological Review 73 (4): 519-542. doi: Doi 10.1177/000312240807300401.

Leisink, Peter, and Bram Steijn. 2009. Public service motivation and job performance of public sector employees in the Netherlands. International Review of Administrative Sciences 75 (1): 35-52. doi: Doi $10.1177 / 0020852308099505$.

Light, Paul C. 2002. The content of their character: The state of the nonprofit workforce. The Nonprofit Quarterly 9 (3): 6-16.

Loewenthal, Kate Miriam. 2004. An Introduction to Psychological Tests and Scales. Hove (UK): Psychology Press.

Lyons, Sean T., Linda E. Duxbury, and Christopher A. Higgins. 2006. A Comparison of the Values and Commitment of Private Sector, Public Sector, and Parapublic Sector Employees. Public Administration Review 66 (4): 605-618.

Mann, Gregory A. 2006. A motive to serve: public service motivation in human resource management and the role of PSM in the nonprofit sector. Public Personnel Management 35 (1): 33(16).

Maslach, Christina, Wilmar B. Schaufeli, and Michael P. Leiter. 2001. Job Burnout. Annual Review of Psychology 52: 397-422.

Meek, Lynn V. 1988. Organizational Culture: Origins and Weaknesses. Organization Studies 9 (4): 453-473.

Natsios, Andrew. 2010. The clash of the counter-bureaucracy and development. Center for Global Development www.cgdev.org/content/publications/detail/1424271.

Ness, Gayl D., and Steven R. Brechin. 1988. Bridging the gap: international organizations as organizations. International Organization 42 (02): 245-273. doi: doi:10.1017/S0020818300032811.

Pandey, Sanjay K., and Gordon A. Kingsley. 2000. Examining Red Tape in Public and Private Organizations: Alternative Explanations from a Social Psychological Model. Journal of Public Administration Research and Theory 10 (4): 779-799.

Perry, James L, and Annie Hondeghem. 2008. Motivation in Public Management: The Call of Public Service. New York: Oxford University Press.

Perry, James L. 1996. Measuring Public Service Motivation: An Assessment of Construct Reliability and Validity. Journal of Public Administration Research and Theory 6 (1): 5-22. 
Perry, James L., and Lois Recascino Wise. 1990. The Motivational Bases of Public Service. Public Administration Review 50 (3): 367-373.

Podsakoff, Philip M., Scott B. MacKenzie, Jeong-Yeon Lee, and Nathan P. Podsakoff. 2003. Common method biases in behavioral research: a critical review of the literature and recommended remedies. Journal of Applied Psychology 88 (5): 879-903. doi: 10.1037/0021-9010.88.5.879.

Preacher, Kristopher J., and Geoffrey J. Leonardelli. 2001. Calculation for the Sobel Test: An Interactive Calculation Tool for Mediation Tests. from: http://www.psych.ku.edu/preacher/sobel/sobel.htm.

Rainey, Hal G. 1983. Public agencies and private firms: Incentives, goals, and individual roles. Administration and Society 15 (2): 207-242.

Rainey, Hal G., and Barry Bozeman. 2000. Comparing public and private organizations: empirical research and the power of the a priori. Journal of Public Administration Research and Theory 10 (2): 447469.

Reinalda, Bob. 2013. Routledge Handbook of International Organization. New York: Routledge.

Rhoades, Linda, Robert Eisenberger, and Stephen Armeli. 2001. Affective commitment to the organization: the contribution of perceived organizational support. Journal of Applied Psychology 86 (5): 825836.

Ritz, Adrian, Gene A. Brewer, and Oliver Neumann. 2016. Public Service Motivation: A Systematic Literature Review and Outlook. Public Administration Review 76 (3): 414-426. doi: 10.1111/puar.12505. Salomons, Dirk. 2004. Good Intentions to Naught. The Pathology of Human Resources Management at the United Nations. In Rethinking international organizations: pathology and promise, edited by Dennis Dijkzeul and Yves Beigbeder, 111-139. New-York: Berghahn Books.

Schein, Edgar H. 1990. Organizational culture. American Psychologist 45 (2): 109-119.

Schemeil, Yves. 2013. Bringing International Organization In: Global Institutions as Adaptive Hybrids. Organization Studies 34 (2): 219-252. doi: 10.1177/0170840612473551.

Scott, Patrick G., and Sanjay K. Pandey. 2005. Red Tape and Public Service Motivation. Review of Public Personnel Administration 25 (2): 155-180.

Spector, Paul E. 1985. Measurement of human service staff satisfaction: Development of the Job Satisfaction Survey. American Journal of Community Psychology 13 (6): 693-713. 
Spector, Paul E. 1994. Using Self-Report Questionnaires in OB Research: A Comment on the Use of a Controversial Method. Journal of Organizational Behavior 15: 385-392.

Steen, Trui. 2008. Not a Governement Monopoly: the Private, Nonprofit, and Voluntary Sectors. In Motivation in Public Management: The Call of Public Service, edited by James L Perry and Annie Hondeghem, 203-222. New York: Oxford University Press.

Steijn, Bram. 2008. Person-Environment Fit and Public Service Motivation. International Public Management Journal 11 (1): 13-27. doi: 10.1080/10967490801887863.

Steinhaus, Carol S., and James L. Perry. 1996. Organizational commitment: Does sector matter? Public Productivity \& Management Review 19 (3): 278-288.

Su, Sophia, Kevin Baird, and Bill Blair. 2009. Employee organizational commitment: the influence of cultural and organizational factors in the Australian manufacturing industry. International Journal of Human Resource Management 20 (12): 2494-2516. doi: 10.1080/09585190903363813.

Taylor, Jeanette. 2010. Public Service Motivation, Civic Attitudes and Actions of Public, Nonprofit and Private Sector Employees. Public Administration 88 (4): 1083-1098.

Taylor, Jeannette. 2007. The impact of public service motives on work outcomes in Australia: A comparative multi-dimensional analysis. Public Administration 85 (4): 931-959.

Taylor, Jeannette, and Ranald Taylor. 2011. Working Hard for More Money or Working Hard to Make a Difference? Efficiency Wages, Public Service Motivation, and Effort. Review of Public Personnel Administration 31 (1): 67-86. doi: 10.1177/0734371x10394401.

Thomas, Alexander R., and Polly J. Smith. 2003. Spotlight on Social Research. Boston: Pearson Education. United Nations. 1945. United Nations Charter. San Francisco.

United Nations. 1948. Universal Declaration of Human Rights. Paris.

United Nations. 2009. Staff Regulations of the United Nations. In $S T / S G B / 2009 / 6$ New York: United Nations. van Loon, Nina, Anne Mette Kjeldsen, Lotte Bøgh Andersen, Wouter Vandenabeele, and Peter Leisink. 2016.

Only When the Societal Impact Potential Is High? A Panel Study of the Relationship Between Public Service Motivation and Perceived Performance. Review of Public Personnel Administration. doi: 10.1177/0734371x16639111.

Vandenabeele, Wouter. 2009. The mediating effect of job satisfaction and organizational commitment on selfreported performance: more robust evidence of the PSM-performance relationship. International Review of Administrative Sciences 75 (1): 11-34. 
Vandenabeele, Wouter, and Carolyn Ban. 2009. The impact of public service motivation in an international organization: job satisfaction and organizational commitment in the European Commission. International Public Service Motivation Conference, Bloomington, Indiana, 7-9 June 2009.

Vaux, Tony. 2001. The Selfish Altruist: Relief Work in Famine and War. London/Sterling: Earthscan/James \& James.

Weiss, Thomas G. 2010. The John W. Holmes Lecture: Reinvigorating the International Civil Service. Global Governance 16 (1): 39-57.

Weiss, Thomas G. 2012. What's Wrong with the United Nations and how to Fix it. Cambridge: Polity Press.

Whetten, David A. 2006. Albert and Whetten Revisited: Strengthening the Concept of Organizational Identity. Journal of Management Inquiry 15 (3): 219-234.

Wright, Bradley E., and Robert K. Christensen. 2009. Public Service Motivation: Testing Measures, Antecedents and Consequences. International Public Service Motivation Research Conference, Bloomington, Indiana, 7-9 June 2009.

Wright, Bradley E., and Sanjay K. Pandey. 2008. Public Service Motivation and the Assumption of PersonOrganization Fit. Testing the Mediating Effect of Value Congruence. Administration \& Society 40 (5): 502-521.

\section{[Appendix 1 here]}

\section{[Appendix 2 here]}


Figures, tables, and appendixes

Figure 1: Theoretical framework

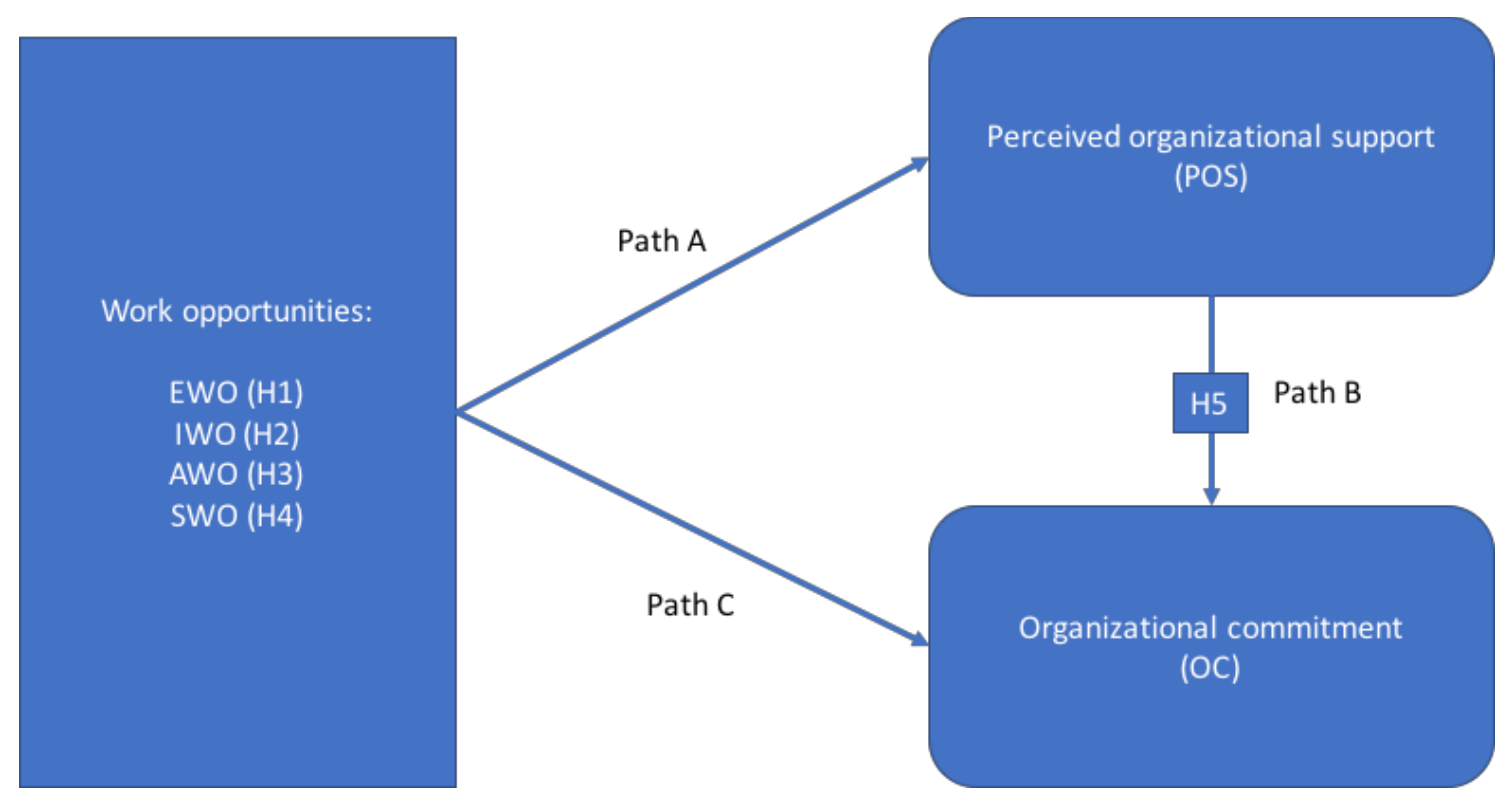


Table 1: Description of the Sample

\begin{tabular}{|c|c|}
\hline Sex* & Type of IO \\
\hline Men: 497 (46.8\%) & Humanitarian: $1459(83.1 \%)$ \\
\hline Women: $564(53.2 \%)$ & Technical: $296(16.9 \%)$ \\
\hline Age Categories** & Origin*** \\
\hline 19-29: $78(8.6 \%)$ & Africa: $167(17.4 \%)$ \\
\hline 30-39: 295 (32.4\%) & Asia-Pacific: 210 (21.9 \%) \\
\hline 40-49: $309(33.9 \%)$ & Eastern Europe: 93 (9.7\%) \\
\hline 50-59: $215(23.6 \%)$ & Latin America and the Caribbean: $65(6.8 \%)$ \\
\hline 60-62: $12(1.3 \%)$ & Western Europe and Others: 424 (44.2\%) \\
\hline \multicolumn{2}{|l|}{$63-65: 2(0.2 \%)$} \\
\hline Average Organizational Tenure & Employment Categories \\
\hline \multirow[t]{2}{*}{9.5 years } & Paid employees: 1728 (97.7\%) \\
\hline & Interns/volunteers: $41(2.3 \%)$ \\
\hline
\end{tabular}

$\mathrm{N}=1769, * 60 \%$, resp. $* * 51.5 \%, * * * 54.2 \%$ answered the questions 
Table 2: Hierarchical regression on POS (path A)

\begin{tabular}{|c|c|c|c|c|c|c|}
\hline & \multicolumn{3}{|c|}{ Model 1} & \multicolumn{3}{|c|}{ Model 2} \\
\hline & $B$ & Standard error & Beta & $B$ & Standard error & Beta \\
\hline Age & .065 & .048 & .057 & .023 & .037 & .020 \\
\hline Gender & -.389 & .074 & $-.177 * * *$ & -.311 & .058 & $-.142 * * *$ \\
\hline Educational level & -.079 & .051 & -.0 .61 & -.031 & .039 & -.024 \\
\hline Organizational tenure & -.022 & .006 & $-.144 * *$ & -.015 & .005 & $-.101 * *$ \\
\hline Work location & .398 & .075 & $.181 * * *$ & .338 & .059 & $.153 * * *$ \\
\hline Local-expatriate & -.302 & .084 & $-.137 * * *$ & -.310 & .065 & $-.141 * * *$ \\
\hline EWO & & & & .351 & .041 & $.290 * * *$ \\
\hline IWO & & & & .193 & .041 & $.164 * * *$ \\
\hline AWO & & & & .219 & .038 & $.157 * * *$ \\
\hline SWO & & & & .249 & .036 & $.221 * * *$ \\
\hline $\mathrm{R}^{2}$ adjusted & & .102 & & & .459 & \\
\hline Model F & & $16.100^{* * *}$ & & & $68.879^{*}$ & \\
\hline $\mathrm{N}$ & & 607 & & & 607 & \\
\hline \multicolumn{7}{|c|}{$\begin{array}{l}* \text { Significant at the level of .05 } \\
* * \text { Significant at the level of } .01 \\
* * * \text { Significant at the level of } .001 \\
\text { Exclude cases listwise }\end{array}$} \\
\hline
\end{tabular}


Table 3: Hierarchical regression on OC (path C)

\begin{tabular}{|c|c|c|c|c|c|c|}
\hline & \multicolumn{3}{|c|}{ Model 3} & \multicolumn{3}{|c|}{ Model 4} \\
\hline & $B$ & Standard error & Beta & $B$ & Standard error & Beta \\
\hline Age & .025 & .043 & .028 & .003 & .034 & .003 \\
\hline Gender & -.091 & .066 & -.055 & -.022 & .052 & -.013 \\
\hline Educational level & .040 & .046 & .039 & .064 & .036 & .062 \\
\hline Organizational tenure & -.009 & .006 & -.079 & -.002 & .005 & -.019 \\
\hline Work location & .315 & .067 & $.187 * * *$ & .169 & .054 & $.100 * *$ \\
\hline Local-expatriate & -.193 & .075 & $-.115^{* *}$ & -.112 & .060 & -.067 \\
\hline EWO & & & & .116 & .038 & $.127 * *$ \\
\hline IWO & & & & .035 & .040 & .039 \\
\hline AWO & & & & .555 & .035 & $.511 * * *$ \\
\hline SWO & & & & .139 & .032 & $.161 * * *$ \\
\hline $\mathrm{R}^{2}$ adjusted & \multicolumn{3}{|c|}{.049} & \multicolumn{3}{|c|}{.411} \\
\hline Model F & \multicolumn{3}{|c|}{$6.330 * * *$} & \multicolumn{3}{|c|}{$43.966 * * *$} \\
\hline $\mathrm{N}$ & \multicolumn{3}{|c|}{607} & \multicolumn{3}{|c|}{607} \\
\hline \multicolumn{7}{|c|}{$\begin{array}{l}* \text { Significant at the level of .05 } \\
* * \text { Significant at the level of } .01 \\
* * * \text { Significant at the level of } .001 \\
\text { Exclude cases listwise }\end{array}$} \\
\hline
\end{tabular}


Table 4: Mediation models

\begin{tabular}{|c|c|c|c|}
\hline & & Model 5 & Model 6 \\
\hline & & $\begin{array}{c}\text { B } \\
\text { (Std. Error) }\end{array}$ & $\begin{array}{c}\text { B } \\
\text { (Std. Error) }\end{array}$ \\
\hline $\begin{array}{l}\text { Step 1: } \\
\text { Independent }\end{array}$ & EWO & $\begin{array}{c}.105^{* * *} \\
(.025)\end{array}$ & $\begin{array}{l}.039 \\
(.026)\end{array}$ \\
\hline vallauics & AWO & $\begin{array}{l}.544 * * * \\
(.026)\end{array}$ & $\begin{array}{l}.502 * * * \\
(.026)\end{array}$ \\
\hline & SWO & $\begin{array}{c}.199 * * * \\
(.023)\end{array}$ & $\begin{array}{c}.137 * * * \\
(.024)\end{array}$ \\
\hline Step 2: Stress & POS & & $\begin{array}{c}.199 * * * \\
(.023)\end{array}$ \\
\hline & $\mathrm{R} 2$ & .406 & .431 \\
\hline & R2 change & n.a. & .025 \\
\hline & $\mathrm{F}$ & $229.680 * * *$ & $190.414 * * *$ \\
\hline & $\begin{array}{r}\text { Adjusted } \\
\text { R2 }\end{array}$ & .404 & .428 \\
\hline & F statistic & $75.764 * * *$ & $67.344 * * *$ \\
\hline $\mathrm{p}<.05 * / \mathrm{p}<.0$ & $<.001$ & & \\
\hline
\end{tabular}


Table 5: Testing partial mediation effects of OC (Sobel test)

\begin{tabular}{|l|c|c|c|c|c|}
\hline & Ba & $\beta b$ & SEa & SEb & Z \\
\hline EWO & $.290^{* * *}$ & $.431^{* * *}$ & .041 & .021 & $6.68^{* * *}$ \\
\hline AWO & $.157^{* * *}$ & $.431^{* * *}$ & .038 & .021 & $4.04^{* * *}$ \\
\hline SWO & $221 * * *$ & $.431^{* * *}$ & 0.36 & .021 & $5.88^{* * *}$ \\
\hline $\mathrm{p}<.05 * / \mathrm{p}<.01 * * / \mathrm{p}<.001 * * *$ & & & \\
\hline
\end{tabular}


Table 6: Summary of the results

\begin{tabular}{|c|c|c|c|c|}
\hline & \multicolumn{2}{|r|}{ Hypotheses } & OC & POS \\
\hline \multirow{4}{*}{$\begin{array}{l}\text { Independent } \\
\text { variables }\end{array}$} & $\mathrm{H} 1$ & $\begin{array}{l}\text { Satisfaction with extrinsic work opportunities (EWO) } \\
\text { leads to higher levels of OC and POS }\end{array}$ & $\mathbf{X}$ & $\mathbf{X}$ \\
\hline & $\mathrm{H} 2$ & $\begin{array}{l}\text { Satisfaction with intrinsic work opportunities (IWO) leads } \\
\text { to higher levels of OC and POS }\end{array}$ & & $\mathbf{X}$ \\
\hline & $\mathrm{H} 3$ & $\begin{array}{l}\text { Satisfaction with social work opportunities (SWO) leads to } \\
\text { higher levels of OC and POS }\end{array}$ & $\mathbf{X}$ & $\mathbf{X}$ \\
\hline & $\mathrm{H} 4$ & $\begin{array}{l}\text { Satisfaction with altruistic work opportunities (AWO) } \\
\text { leads to higher levels of OC and POS }\end{array}$ & $\mathbf{X}$ & $\mathbf{X}$ \\
\hline Mediation & H5 & $\begin{array}{l}\text { POS mediates the relationship between job work } \\
\text { opportunities and OC }\end{array}$ & \multicolumn{2}{|c|}{$\begin{array}{l}\text { Partial mediation confirmed } \\
\text { for AWO and SWO. } \\
\text { Full mediation confirmed for } \\
\text { EWO. }\end{array}$} \\
\hline
\end{tabular}




\begin{tabular}{|c|c|c|}
\hline \multicolumn{3}{|c|}{ Appendix 1: Items used in this research } \\
\hline & Variable name & Measurement details \\
\hline \multirow{6}{*}{ 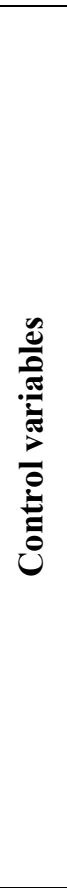 } & Age & $\begin{array}{l}\text { Five categories: } \\
0-29=1 \\
30-39=2 \\
40-49=3 \\
50-59=4 \\
60 \text { and more }=5\end{array}$ \\
\hline & Gender & $\begin{array}{l}\text { Male }=1 \\
\text { Female = 2 }\end{array}$ \\
\hline & $\begin{array}{l}\text { Organizational } \\
\text { tenure }\end{array}$ & How long have you spent in your current organization? \\
\hline & $\begin{array}{l}\text { Educational } \\
\text { level }\end{array}$ & $\begin{array}{l}\text { What is the highest educational level that you have achieved? } \\
\text { Responses coded from } 1 \\
\text { (compulsory school) to } 7 \\
\text { (PhD) }\end{array}$ \\
\hline & Work location & $\begin{array}{l}\text { Where do you spend most of your working time? } \\
1=\text { headquarters } \\
2=\text { field or frequently moves between the field and the headquarters }\end{array}$ \\
\hline & $\begin{array}{l}\text { Local- } \\
\text { expatriate }\end{array}$ & $\begin{array}{l}\text { Are you a local employee or an expatriate? } \\
1=\text { local employee } \\
2=\text { expatriate }\end{array}$ \\
\hline \multirow{4}{*}{ 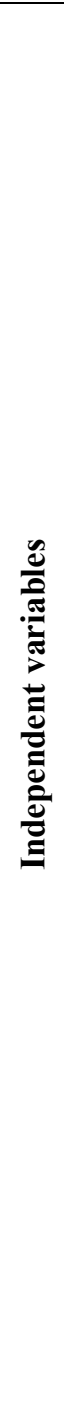 } & $\begin{array}{l}\text { Extrinsic work } \\
\text { opportunities } \\
\text { (EWO) }\end{array}$ & $\begin{array}{l}\text { For each of the statements below, please indicate the extent of your } \\
\text { satisfaction or dissatisfaction by placing a tick in the appropriate box } \\
\text { ( } 1=\text { not satisfied at all; } 5=\text { totally satisfied): } \\
\text { - the adequacy of pay for the work done } \\
\text { - the pay raise } \\
\text { - the benefits I receive } \\
\text { - the benefits compared with those of other similar organizations } \\
\text { - the job security I have }\end{array}$ \\
\hline & $\begin{array}{l}\text { Intrinsic work } \\
\text { opportunities } \\
\text { (IWO) }\end{array}$ & $\begin{array}{l}\text { For each of the statements below, please indicate the extent of your } \\
\text { satisfaction or dissatisfaction by placing a tick in the appropriate box } \\
(1=\text { not satisfied at all; } 5=\text { totally satisfied): } \\
\text { - the responsibilities given to employees } \\
\text { - the open communication among employees } \\
\text { - the provision of training programs for new employees } \\
\text { - the proposed training programs } \\
\text { - the provision of career improvement training programs }\end{array}$ \\
\hline & $\begin{array}{l}\text { Altruistic work } \\
\text { opportunities } \\
\text { (AWO) }\end{array}$ & $\begin{array}{l}\text { For each of the statements below, indicate the extent of your agreement or } \\
\text { disagreement by placing a tick in the appropriate box } \\
\text { ( } 1 \text { = strongly disagree; } 5 \text { = disagree agree): } \\
\text { - I am interested in making international programs that contribute to } \\
\quad \text { building a } \\
\text { better world } \\
\text { - Seeing people receive benefits from the programs I have been deeply } \\
\text { involved in } \\
\text { brings me a great deal of satisfaction } \\
\text { - I consider my commitment to international civil service my civic duty } \\
\text { - Meaningful international civil service is very important to me } \\
\text { - Making a difference for a better world means more to me than personal } \\
\text { achievements } \\
\text { - I am prepared to make great sacrifices for the good of the whole world }\end{array}$ \\
\hline & $\begin{array}{l}\text { Social work } \\
\text { opportunities } \\
\text { (SWO) }\end{array}$ & $\begin{array}{l}\text { For each of the statements below, please indicate the extent of your } \\
\text { satisfaction or dissatisfaction by placing a tick in the appropriate box } \\
(1=\text { not satisfied at all; } 5=\text { totally satisfied): } \\
\text { - my colleagues' competence } \\
\text { - the work atmosphere among co-workers }\end{array}$ \\
\hline
\end{tabular}




\begin{tabular}{|c|c|c|}
\hline & & $\begin{array}{l}\text { - my supervisor's competence } \\
\text { - my supervisor's fairness } \\
\text { - my supervisor's people skills } \\
\text { - my supervisor's likeability }\end{array}$ \\
\hline 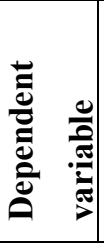 & $\begin{array}{l}\text { Organizational } \\
\text { commitment } \\
\text { (OC) }\end{array}$ & $\begin{array}{l}\text { For this statement below, please indicate the extent of your agreement or } \\
\text { disagreement }(1=\text { disagree strongly; } 5=\text { agree strongly): } \\
\text { - I am willing to put in a great deal of effort beyond what is normally } \\
\text { accepted to help this organization become successful } \\
\text { - I am proud to tell others that I am part of this organization } \\
\text { - I find that my values and the organization's values are similar }\end{array}$ \\
\hline : & $\begin{array}{l}\text { Perceived } \\
\text { organizational } \\
\text { support }\end{array}$ & $\begin{array}{l}\text { For this statement below, please indicate the extent of your agreement or } \\
\text { disagreement }(1=\text { disagree strongly; } 5=\text { agree strongly): } \\
-\quad \text { My organization takes pride in my accomplishments at work } \\
-\quad \text { My organization truly cares about my well-being } \\
-\quad \text { My organization values my contribution to its well-being } \\
-\quad \text { My organization seriously considers my goals and values } \\
-\quad \text { My organization is willing to help me when I need a special favor }\end{array}$ \\
\hline
\end{tabular}




\begin{tabular}{|c|c|c|c|c|c|c|c|c|c|c|c|c|c|c|c|c|}
\hline & & Appendix & 2: Meal & s, stal & dard dev & iation (S) & ), correla & tions for & le variab & es $(N=57$ & & & & & & \\
\hline & & & Mean & SD & 1 & 2 & 3 & 4 & 5 & 6 & 7 & 8 & 9 & 10 & 11 & 12 \\
\hline 1 & $\mathrm{OC}$ & & 3.88 & .83 & 1 & & & & & & & & & & & \\
\hline 2 & POS & & 2.73 & 1.09 & $.431 * *$ & 1 & & & & & & & & & & \\
\hline 3 & Age & & 2.75 & .95 & $-.027^{*}$ & -.041 & 1 & & & & & & & & & \\
\hline 4 & Gender & & 1.51 & .50 & .079 & $-.189^{* *}$ & $-.100 * *$ & 1 & & & & & & & & \\
\hline 5 & Educatio & ll level & 5.60 & .79 & .027 & $-.077^{*}$ & $-.067 *$ & -.009 & 1 & & & & & & & \\
\hline 6 & Organiza & onal tenure & 9.37 & 7.15 & -.052 & $-.107 * *$ & $.585^{* *}$ & $\begin{array}{l}.046 \\
\end{array}$ & $-.205^{* *}$ & 1 & & & & & & \\
\hline 7 & Work loc & tion & 1.71 & .63 & $.201 * *$ & $.195^{* *}$ & $-.096^{* *}$ & $-.105 * *$ & $.084 * *$ & -.037 & 1 & & & & & \\
\hline 8 & Local-ex & atriate & 1.60 & .49 & $-.060 *$ & -.160 ** & $.130^{* *}$ & -.040 & $.430 * *$ & $.072 *$ & -.009 & 1 & & & & \\
\hline 9 & EWO & & 2.98 & .90 & $.259 * *$ & $.496 * *$ & .067 & -.034 & -.036 & .033 & -.045 & .045 & 1 & & & \\
\hline 10 & IWO & & 2.74 & .91 & $.277 * *$ & $.477 * *$ & $.099 * *$ & $-.077 *$ & -.023 & .039 & -.007 & .024 & $.601^{* *}$ & 1 & & \\
\hline 11 & AWO & & 4.03 & .76 & $.581^{* *}$ & $.291 * *$ & -.049 & -.038 & -.001 & -.063 & $.200 * *$ & $-.088 * *$ & $.120 * *$ & $.115^{* *}$ & 1 & \\
\hline 12 & SWO & & 3.46 & .94 & $.313^{* *}$ & $.486^{* *}$ & -.057 & -.053 & -.054 & $-.088^{* *}$ & .041 & -.055 & $.447 * *$ & $.525 * *$ & $.122 * *$ & 1 \\
\hline & & $\begin{array}{l}* \text { Correlati } \\
* * \text { Correla } \\
\text { Exclude ca }\end{array}$ & $\begin{array}{l}\text { on is sig } \\
\text { tion is si } \\
\text { ses listy }\end{array}$ & $\begin{array}{l}\text { iifican } \\
\text { nifica } \\
\text { ise }\end{array}$ & $\begin{array}{l}\text { at the } 0 . \\
\text { at at the } 0\end{array}$ & $\begin{array}{l}5 \text { level (2 } \\
.01 \text { level }\end{array}$ & $\begin{array}{l}\text { tailed) } \\
\text { 2-tailed) }\end{array}$ & & & & & & & & & \\
\hline
\end{tabular}

